\title{
Morphology of the lingual papillae in the leopard
}

\author{
By \\ Shoichi EMURA \\ Heisei College of Health Sciences, Gifu-shi, Gifu 501-1131, Japan \\ -Received for Publication, August 31, 2018 -
}

\begin{abstract}
Key Words: leopard, lingual papillae, scanning electron microscopy
Summary: We microscopically examined the dorsal lingual surface of an old leopard (Panthera pardus). The filiform papillae on the lingual apex were dome-shaped. The connective tissue cores of the filiform papillae resembled a well in shape, while those of the fungiform papillae were not hollow. The filiform papillae on the anterior part of the lingual body were large and cylindrical in shape. The connective tissue cores of these filiform papillae consisted of large conical papillae. The filiform papillae on the central part of the lingual body were large and conical-shaped. The connective tissue cores of the filiform papillae consisted of a large main process. The vallate papillae were surrounded by grooves. The top of the connective tissue core of the vallate papilla had many ditches. These findings are peculiar to the tongue of members of the family Felidae.
\end{abstract}

Many studies have reported on the structures of the lingual surfaces of various animals. Scanning electron microscopy (SEM) studies have been conducted on the tongues of the cat (Boshell et al., 1982), dog (Iwasaki and Sakata, 1985), mongoose (Iwasaki et al., 1987), Japanese weasel (Furubayashi et al., 1989), sea otter (Shimoda et al., 1996), bush dog (Emura et al., 2000), newborn panther and Asian black bear (Emura et al., 2001), lion (Emura et al., 2003), tiger (Emura et al., 2004), jaguar (Emura et al., 2013), fishing cat (Emura et al., 2014), and blackbacked jackal (Emura et al., 2014) belonging to the order Carnivora. Such studies have revealed variations in the morphology and distribution of papillae on the dorsal lingual surface among these species.

The purpose of this study was to examine threedimensionally the dorsal lingual surface and the connective tissue core of the leopard, and compare the results with those of previous reports on other mammals.

\section{Materials and Methods}

The tongue of one old leopard of the family Felidae was used in this study. The tongue was fixed in 10\% formalin. Small blocks containing papillae were cut with a razor blade and post-fixed with $1 \%$ osmium tetroxide for $1 \mathrm{~h}$. Thereafter, the specimens were dehydrated through a graded series of acetone exchange fluids and criticalpoint-dried. To examine the three-dimensional connective tissue structure of the lamina propria of the mucosa, some of the samples were washed in distilled water after fixation and macerated in $3.5 \mathrm{~N} \mathrm{HCl}$ at $35^{\circ} \mathrm{C}$ for $3 \mathrm{~d}$. After maceration, the tissues were washed in distilled water, post-fixed in $1 \%$ osmium tetroxide for $1 \mathrm{~h}$, and dehydrated in a series of acetone exchange fluids and criticalpoint-dried. All specimens were sputtered with Pt-Pd before examination by SEM (Hitachi S-3500N, Tokyo, Japan) at an accelerating voltage of $10 \mathrm{kV}$.

\section{Results}

Macroscopically, the tongue of the leopard was about $20 \mathrm{~cm}$ long. Filiform papillae are distributed over the entire dorsal surface of the lingual body (Fig. 1). There were no foliate papillae. Vallate papillae were located on both sides of the posterior end of the lingual body (Fig. 1).

SEM analysis revealed that the filiform papillae on the lingual apex were dome-shaped (Fig. 2a). The connective tissue cores of the filiform papillae resembled a well in shape, while those of the fungiform papillae were not hollow (Fig. 2b). The filiform papillae on the anterior part of the lingual body were large and cylindrical in shape (Fig. 2c). The connective tissue cores of these filiform 


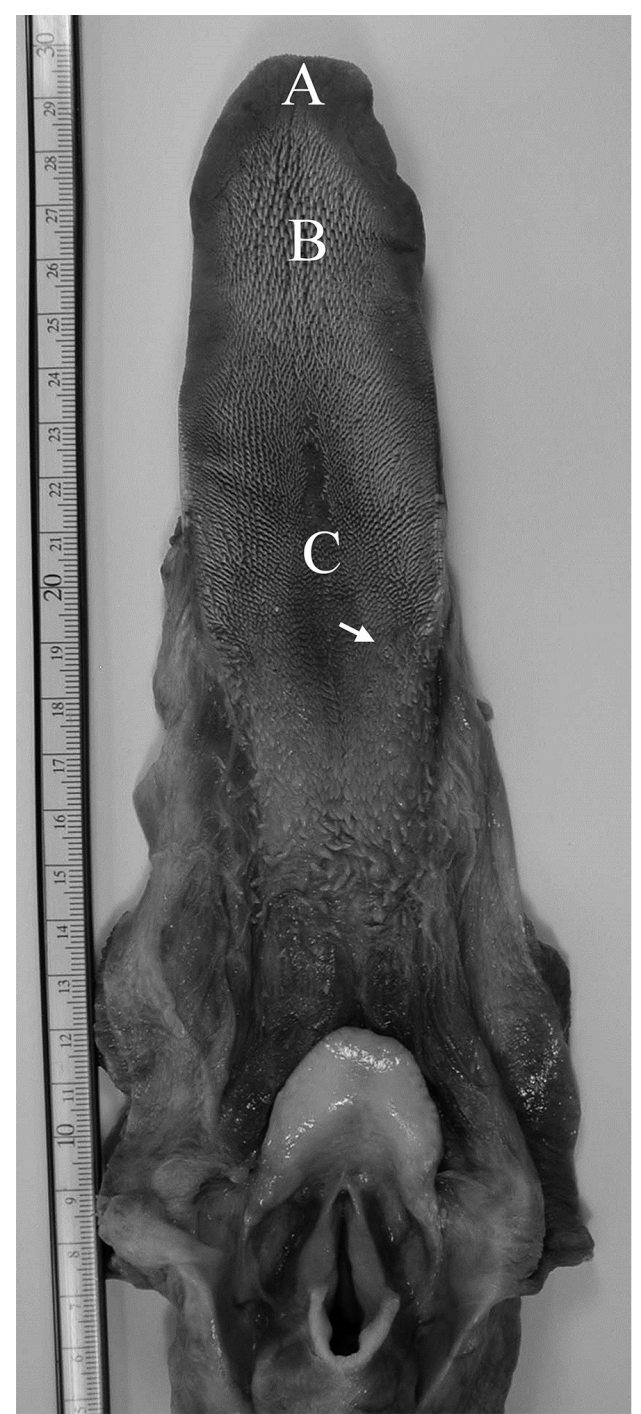

Fig. 1. Macrograph of leopard tongue. A, B, C, and arrows show the parts prepared for scanning electron microscopy (SEM).
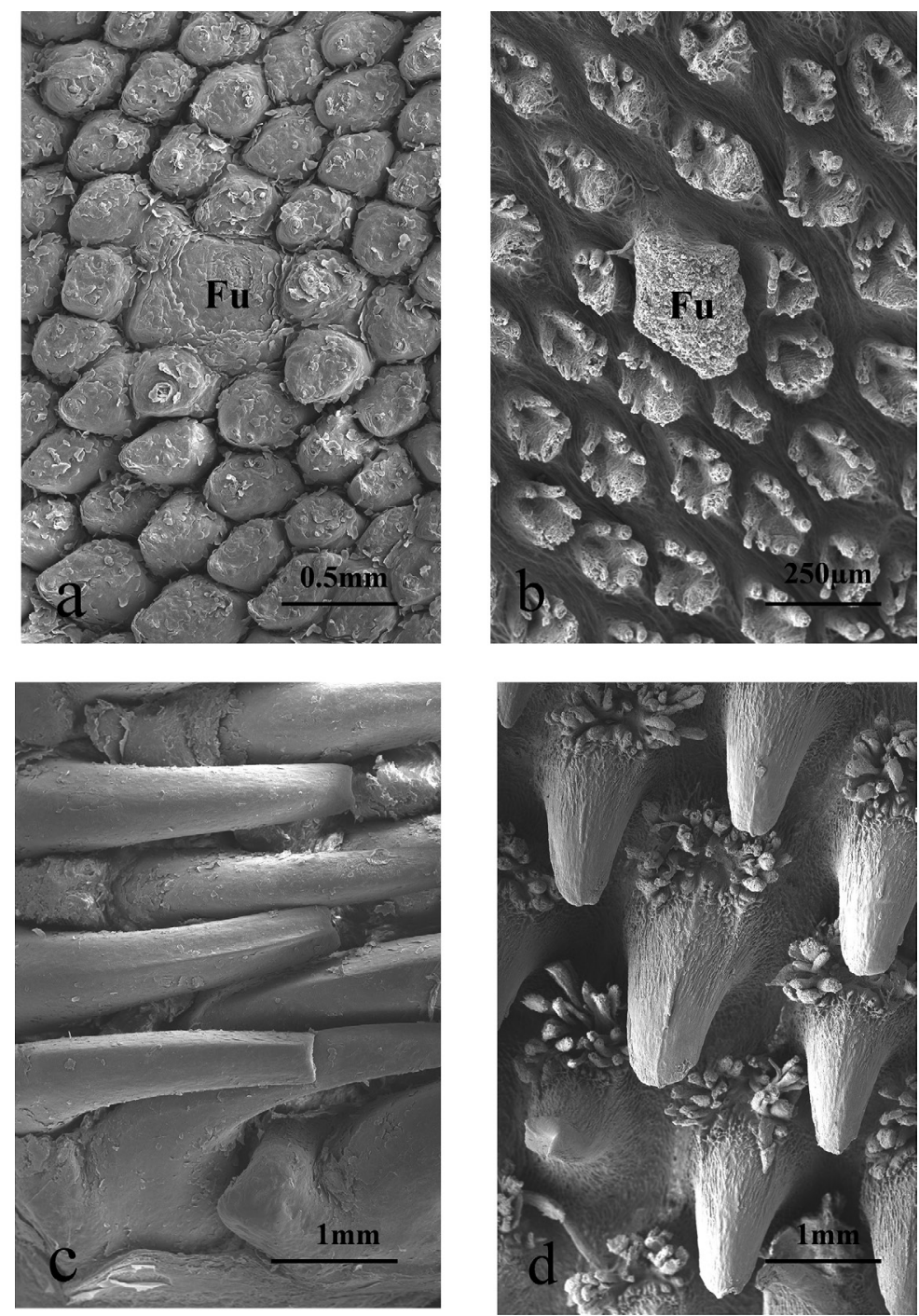

Fig. 2. (a, b) SEM micrographs of A in Fig. 1. The filiform papillae on the lingual apex were dome-shaped. The connective tissue cores of the filiform papillae resemble a well in shape, while those of the fungiform papillae (Fu) are not hollow. (c, d) SEM micrographs of B in Fig. 1. The filiform papillae on the anterior part of the lingual body are large and cylindrical in shape. The connective tissue cores of these filiform papillae consist of large conical papillae. papillae consisted of large conical papillae (Fig. 2d). The filiform papillae on the central part of the lingual body were large and conical-shaped (Fig. 3a). The connective tissue cores of the filiform papillae consisted of a large main process (Fig. 3b). The vallate papillae were surrounded by grooves (Fig. 3c). The top of the connective tissue core of the vallate papilla had many ditches (Fig. $3 d)$.

\section{Discussion}

Shimoda et al. (1996) reported that the filiform papil- lae on the margin of the tongue of a newborn sea otter are divided into two shapes: horned and club-shaped, and the fungiform papillae are divided into hemispherical and club-shaped. Emura et al. $(2001,2003)$ reported that large papillae were observed on the margins of the lingual apexes of a newborn panther, a newborn Asian black bear, and a newborn lion. In the cat (Boshell et al., 1982), newborn panther (Emura et al., 2001), lion (Emura et al., 2003), tiger (Emura et al., 2004), jaguar (Emura et al., 2013), and fishing cat (Emura et al., 2014), a marked transition occurs between the tip and mid-portion of the dorsum of the tongue. This transition is characterized by an increase in size of the projections of the filiform papil- 

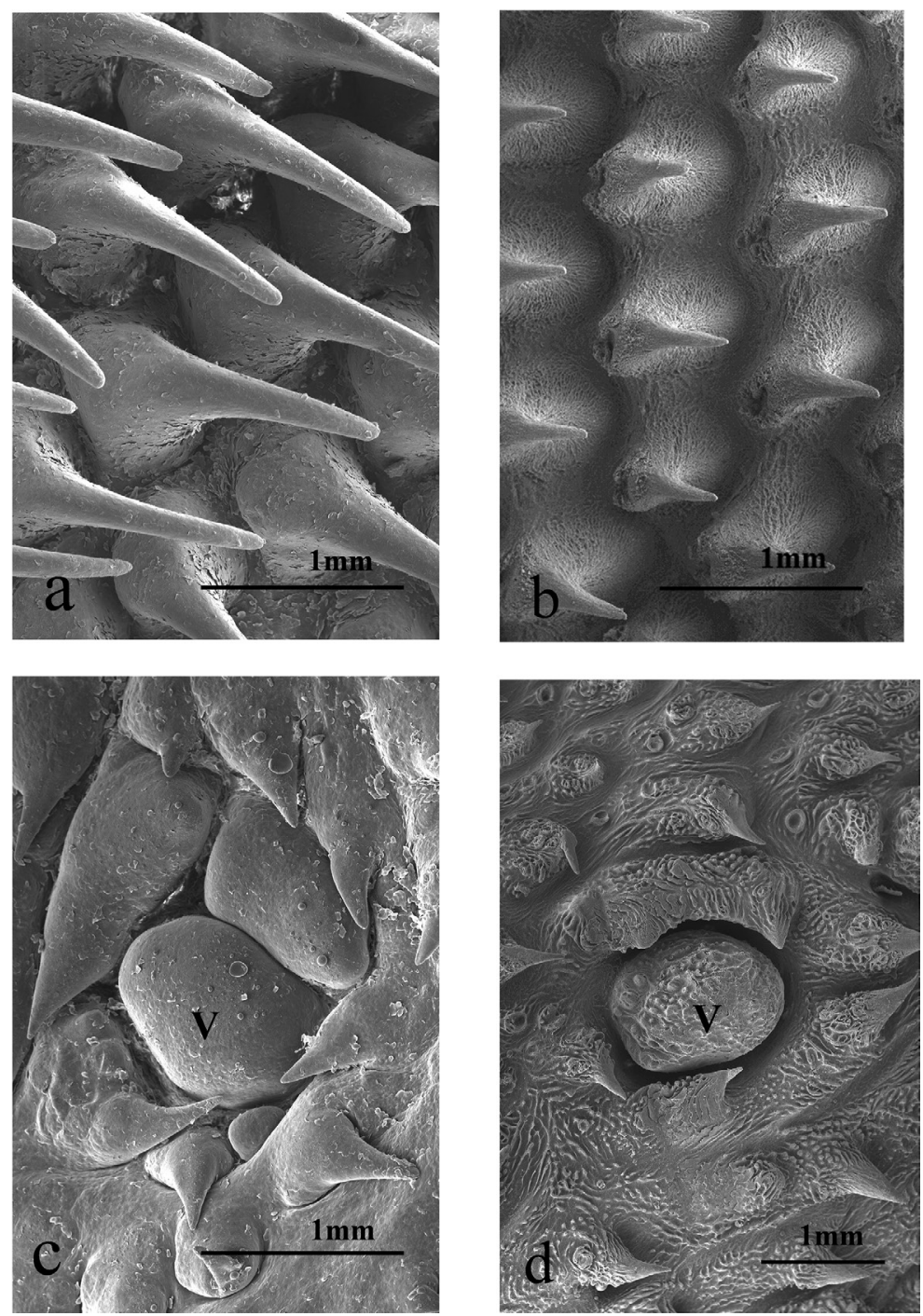

Fig. 3. (a, b) SEM micrographs of C in Fig. 1. The filiform papillae on the central part of the lingual body are large and conical-shaped. The connective tissue cores of the filiform papillae consist of a large main process. (c, d) SEM micrographs of arrows in Fig. 1. The vallate papillae (V) are surrounded by grooves. The top of the connective tissue core of the vallate papilla have many ditches.

lae. In the midportion of the tongue, these projections are very prominent. This finding is fairly consistent with our observations of the tongue of the leopard. Furthermore, the marked regional variation in size and morphology of the filiform papillae in the leopard tongue contrasts with descriptions of tongues in plant-eating animals. The filiform papilla on the lingual apex consists of a large main papilla and some secondary papillae in the fishing cat (Emura et al., 2014). In this study, the filiform papillae on the lingual apex were dome-shaped. This suggests abrasion of the lingual papillae for reasons of old. The connective tissue core of the filiform papilla on the lingual body consists of a large main process and some secondary processes in the jaguar (Emura et al., 2013). This structure is similar to those of the leopard. These reports show that the leopard tongue had a peculiarity of the tongue of the family Felidae. In this study, the filiform papillae on the anterior part of the lingual body were large and cylindrical in shape. However, this papilla is not observed in the newborn panther (Emura et al., 2001). The vallate papillae of the newborn and old leopard consist of the groove and pad (Emura et al., 2001). The development of the vallate papilla is visible earlier than that of the filiform papilla. This finding suggests that the development of the gustatory papilla is visible earlier than that of the mechanical papilla.

Many studies have described the three-dimensional structure of the vallate papillae in the mammalian tongue. In particular, several studies have shown that the vallate papillae are flattened and oval in shape and are sur- 
rounded by a groove and a pad (Krause and Cutts, 1982; Chamorro et al., 1986; Qayyum et al., 1988; Chunhabundit et al., 1992; Agungpriyono et al., 1995; Atoji et al., 1998; Emura et al., 2013). The vallate papillae of the cat, dog, and flying squirrel have been found to be encircled by filiform papillae in the posterior body (Boshell et al., 1982; Iwasaki and Sakata, 1985; Emura et al., 1999). Equine vallate papillae are composed of a primary papilla that is divided into several secondary papillae by intermediate grooves (Chamorro et al., 1986). Occasionally, in bovine vallate papillae, twin papillae are surrounded only by a primary papillary groove (Chamorro et al., 1986). The vallate papillae of the bush dog are surrounded by a groove and a crescent pad, and on the dorsal surfaces of these papillae, small conical papillae have been observed (Emura et al., 2000). The vallate papillae of the lion (Emura et al., 2003) and tiger (Emura et al., 2004) have not small conical papillae on the dorsal surfaces of these papillae. The small conical papilla was not also observed in the leopard in this study.

In conclusion, the morphological characteristics of the tongue in the leopard were found to be similar to those of other members of the family Felidae.

\section{Acknowledgements}

I am grateful to the staff of Osaka Municipal Tennoji Zoological Gardens for supplying the specimen.

\section{References}

1) Atoji Y, Yamamoto $Y$ and Suzuki Y: Morphology of the tongue of a male Formosan serow (Capricornis crispus swinhoei). Anat Histol Embryol 1998: 27:17-19.

2) Agungpriyono S, Yamada J, Kitamura N, Nisa C, Sigit K, Yamamoto Y: Morphology of the dorsal lingual papillae in the lesser mouse deer, Tragulus javanicus. J Anat 1995; 187:635-640.

3) Boshell JL, Wilborn WH, Singh BB: Filiform papillae of cat tongue. Acta Anat 1982; 114:97-105

4) Chamorro CA, de Paz P, Snadval J, Fernandez JG: Comparative scanning electron-microscopic study of the lingual papillae in two species of domestic mammals (Equus caballus and Bos Taurus). I. Gustatory papillae. Acta Anat 1986; 125:83-87.

5) Chunhabundit P, Thongpila S, Somana R: SEM study on the dorsal lingual surface of the common tree shrew, Tupaia glis. Acta Anat 1992; 143:253-257.

6) Emura S, Hayakawa D, Chen H, Shoumura S: Morphology of the dorsal lingual papillae in the newborn panther and Asian black bear. Okajimas Folia Anat Jpn 2001; 78:173-178.

7) Emura S, Hayakawa D, Chen H, Shoumura S: SEM and gross study on the lingual surface of the lion, Panthera leo (in Japanese). Mammalian Science 2003: 43:45-50.

8) Emura S, Hayakawa D, Chen H, Shoumura S: Morphology of the lingual papillae in the tiger. Okajimas Folia Anat Jpn 2004; 81: 39-44.

9) Emura S, Okumura T, Chen H: Morphology of the lingual papillae in the jaguar. Okajimas Folia Anat Jpn 2013; 89:93-97.

10) Emura S, Okumura T, Chen H: Morphology of the lingual papillae in the fishing cat. Okajimas Folia Anat Jpn 2014; 90:79-83.

11) Emura S, Tamada A, Hayakawa D, Chen H, Jamali M, Taguchi H, Shoumura S: SEM study on the dorsal lingual surface of the flying squirrel, Petaurista leucogenys. Ann Anat 1999; 181:495-498.

12) Emura S, Tamada A, Hayakawa D, Chen H, Shoumura S: Morphology of the dorsal lingual papillae in the bush dog (Speothos venaticus). Okajimas Folia Anat Jpn 2000; 77:137-142.

13) Furubayashi R, Sato E, Ishibashi T: Histological pattern of the tongue in the Japanese weasels, Mustera itatsi, with special reference to the morphology and distribution of papillae, taste buds and lingual glands (in Japanese). Acta Anat Nippon 1989; 64:210-214.

14) Iwasaki S, Miyata K, Kobayashi K: Comparative studies of the dorsal surface of the tongue in three mammalian species by scanning electron microscopy. Acta Anat 1987; 128:140-146.

15) Iwasaki S, Sakata K: Scanning electron microscopy of the lingual dorsal surface of the beagle dog. Okajimas Folia Anat Jpn 1985; 62:1-14.

16) Krause WJ, Cutts JH: Morphological observations on the papillae of the opossum tongue. Acta Anat 1982; 113:159-168.

17) Shimoda $T$, Nakanishi E, Yoshino S, Kobayashi S: Light and scanning electron microscopic study on the lingual papillae in the newborn sea otter Enhydra lutris. Okajimas Folia Anat Jpn 1996; 73:65-74.

18) Qayyum MA, Fatani JA, Mohajir AM: Scanning electron microscopic study of the lingual papillae of the one humped camel, Camelus dromedaries. J Anat 1988; 160:21-26. 